time scale for the Pleistocene ice age, and the 'post-glacial' period, the plant and animal remains supplying a key to climatic change. In the framework, established by these disciplines, are placed the discoveries of physical anthropology, that branch of palaeontology which deals with fossil remains of ' man', archaeology, which deals with the surviving works of man's hand, and epigraphy, that branch of archaeology which in its widest sense deals with written records, and their contents. A primary question which must be decided in connection with the prehistoric period is whether or not the 'man' of prehistorians is to be identified with 'man' in the Biblical sense.

The material which probably has the greatest direct relevance to these chapters is the epigraphic, and as written records can preserve matters much earlier than their actual writing down, the inscriptions need not be limited in this context to those dating from the early period. In fact the well-known 'creation' and ' flood' tablets are mainly preserved to us in late recensions. The principal material of this nature is found in the Sumerian and Akkadian cuneiform records of Mesopotamia, and to a lesser extent in the hieroglyphic and hieratic literature of Egypt. The relevant Akkadian inscriptions have been very adequately dealt with recently by the late Dr. Alexander Heidel of Chicago (The Gilgamesh Epic and Old Testament Parallels, 2nd ed. (Chicago, 1949); The Babylonian Genesis, 2nd ed. (Chicago, 1951).), but a large amount of Sumerian literature has recently been published, particularly by Professor S. N. Kramer of Philadelphia, and as it contains elements, such as a flood story, which clearly lie behind some of the Akkadian versions, it is necessary to examine it in the present connection.

Thus the examination of Genesis i-xi involves a careful study of the Hebrew text; a decision as to its intention, historical or poetic; a survey of the results of archaeology from the appearance of man to the second millennium B.C.; an examination of the Sumerian and Akkadian legends relevant to Genesis; and finally a synthesis of this material, consistent with a high view of the inspiration and authority of Scripture.

Tyndale House,

Cambridge.

T. C. MITCHELL.

\title{
Chronicle:
}

\section{RECENT LUTHER STUDIES}

'It is probably true to say that during the past half century more hours of historical research and theological analysis have been devoted to Martin Luther than any other figure in the history of Christianity except its Founder.' Such is the measured statement of Professor E. Harris Harbison of Princeton. It is by no means an exaggeration. In view, therefore, of the vast mass of material at our disposal, we can do no more in this brief survey than touch and glance upon a few of the major studies of Luther which have appeared since the midpoint of this present century. We shall concentrate mainly on those books and articles which appear in English, although it will be necessary at times to allude to outstanding continental works.

The most serious impediment to an understanding of Luther here in Britain has been the lack of adequate and comprehensive translations of his writings. The definitive Weimar edition, which is still incomplete, yields its treasures only to those who can cope with the late medieval Latin and middle high German in which Luther expressed himself. English readers have had to rely on the much slighter selections of Wace and Buchheim, whilst America has produced the editions of Lenker and Holman. In 1955, however, there appeared the first of a fifty-five volume series of Luther's Works, edited by Dr. Jaroslav Pelikan of Chicago, which promises to make good a long-standing deficiency. Thirty exegetical volumes are to be published by the Concordia House of St. Louis and twenty-five volumes of Reformation writings and occasional pieces will issue from the Muhlenberg Press. Volumes 12, 13 and 21 on the Psalms, the Sermon on the Mount and the Magnificat, are already available and maintain an exceptionally high standard. Another less exhaustive series (edited by Bertram Lee Wolf) aims to cover The Reformation Writings of Martin Luther. Only two volumes have so far been offered. The Library of Christian Classics lists four titles relating to Luther, of which the Letters of Spiritual Counsel are now ready. Professor Theodore Tappert has produced a judicious anthology. Dr. Pauck's rendering of the Lectures on Romans will be awaited with the utmost interest: meanwhile we have to be satisfied with J. Theodore Mueller's abbreviated version of 1954 . For the theological significance of this 'Reformation manifesto', as James Mackinnon called it, see my articles in the Scottish Journal of Theology, March and June, 1950. 
The year 1950 marked the advent of two remarkable biographies of Luther. There was urgent need both for a full-length critical treatment and for a shorter popular account. The first is supplied by E. G. Schwiebert in Luther and His Times: The Reformation from a New Perspective. This is indeed a monumental masterpiece. It runs to over 300,000 words, contains almost 3,000 footnotes and includes 65 illustrations. It is a virtually exhaustive biography and yet it is much more. It provides a broad historical outline of the period, sets Luther against his background and indicates the impact of his new theology upon his contemporaries. $\mathrm{He}$ is presented as a Biblical Humanist effecting an educational reformation from the University of Wittenberg. Schwiebert is no stylist and makes little attempt to quicken the imagination. Roland H. Bainton, on the contrary, in Here I Stand: A Life of Martin Luther, brilliantly succeeds in bringing the Reformer to vivid life, and now that a cheap paper-backed edition has been put on the market this will undoubtedly top the bill as the best readable biography of Luther. It is undergirded by sound historical scholarship.

Passing over W. J. Kooiman's By Faith Alone, which rather falls between two stools, we note E. G. Rupp's Luther's Progress to the Diet of Worms, which reviews the spiritual pilgrimage of the one-time Augustinian monk in the lively manner which we have learned to associate with the author. Mention must also be made of the early chapters in Wilhelm Pauck's The Heritage of the Reformation which deal with Luther's theological development. "Whatever the truth about Luther,' wrote Rupp, ' it will never be found by those who by-pass his theology.' The remainder of this bibliography is concerned with various aspects of this vital theme. A useful introduction will be found in the first part of J. S. Whale's The Protestant Tradition, which stresses Luther's positive achievements in the realm of doctrine. He is rightly placed at the head of a line which runs through Pascal and Kierkegaard to the contemporary Biblical theology of encounter. For a more extensive, though indirect, exposition of Lutheran theology the student may be referred to Gustaf Aulén's The Faith of the Christian Church, which breathes the very spirit of Luther and teems with quotations. Another book by Professor Rupp, The Righteousness of God, is occupied in its central section with an examination of the underlying principle of Luther's doctrine as crystallized in the phrase 'coram Deo'. His development from 1509 to 1521 is shown to possess its own coherence and integrity as distinct from earlier Catholic and later Protestant orthodoxy, and the heart of the Reformation is seen to be a crisis of vocabulary. Dr. Rupp has done much to elucidate the relationship between Luther and the Nominalists and on this important subject we must not overlook the article by Bergt Haegglund on 'Was Luther a Nominalist?' (Theology, June, 1956).

Luther's ' article of a standing or a falling Church', namely, justification by faith, is handled by Dr. G. W. Bromiley in The Evangelical Quarterly for April, 1952. A lucid account of varying viewpoints is contained in Luther Discovers the Gospel: New Light upon Luther's Way from Medieval Catholicism to Evangelical Faith by Uuras Saarnivaara followed by a direct challenge to current interpretations, which also runs through Axel Gyllenkrok's Rechtfertigung und Heiligung in der frühen evangelischen Theologie Luthers (Uppsala, 1952). John Dillenberger's God Hidden and Revealed is a study of the concept of 'Deus absconditus' as stated by Luther in his De Servo Arbitrio. Rupp has a valuable article on 'Luther and the Doctrine of the Church' (Scottish Journal of Theology, December, 1956) in which he affirms that 'the magisterial theme of Luther's ecclesiology, and its integrating element, is the doctrine of the Word '. The outstanding volume on Luther's attitude to Christian worship is Vilmos Vajta's Die Theologie des Gottesdienstes hei Luther (Göttingen, 1954). Luther's liturgical reforms are shown to have arisen from his theological presuppositions and his idea of worship is helpfully expounded under a dual analysis as the work of God and the work of faith. Luther's teaching on the Holy Communion is summarized in a comparative study by Hans Grass, Die Abendmahlslehre bei Luther und Calvin (Gütersloh, 1954). Articles include W. H. Baar on 'Luther's Sacramental Thought' (Lutheran Quarterly, 1950), Norman Nagel's 'The Incarnation and the Lord's Supper in Luther ' (Concordia Theological Monthly, 1953) and Edward Quinn's 'Eck, Luther and the Mass' (Downside Review, 1951). Gösta Hök deals with 'Luther's Doctrine of the Ministry' as stemming from his new conception of grace as 'favor Dei' (Scottish lournal of Theology, March, 1954).

One of the most significant books to appear in the period under review is Regin Prenter's Spiritus Creator: Luther's Concept of the Holy Spirit. It was first published in Danish in 1944, but the English translation did not see the light 
of day until 1953. Although Luther's view of the Holy Spirit dominates the whole of his theology it is not always easy to pinpoint his thought. This Dr. Prenter succeeds in doing to a marked degree. Attention is now being given to Luther's hermeneutics and before long we may look for major works on this theme. Raymond F. Surburg has dealt with the historical context in 'The Significance of Luther's Hermeneutics for the Protestant Reformation' (Concordia Theological Monthly, 1953) and more recently J. Theodore Mueller has written, perhaps rather too emphatically, on 'Luther's Doctrine of Inspiration' (Christianity Today, 1957). W. Schwarz's Principles and Problems of Biblical Translation deals with the conflict of the inspirational and philological principles in the work of sixteenth century translation as reflected in the work of Reuchlin, Erasmus and Luther. He rather too neatly inserts Luther into the purely inspirational category, forgetting that recent research suggests that the Biblical humanist in Luther cannot be dismissed. In the realm of Christian Sociology the most useful work to appear is George W. Forell's Faith Active in Love: An Investigation of the Principles Underlying Luther's Social Ethics (cf. my review in the Evangelical Quarterly, April, 1955).

Space forbids any detailed mention of Roman Catholic contributions to this field, which have been considerable and generally marked by a new sympathy and honesty. P. Yves Congar has submitted Luther's ecclesiology to a detailed critique in Vraie et fausse Réforme dans l'Eglise and P. Louis Bouyer examines the fundamentals of his theology in The Spirit and Forms of Protestantism. Those who wish to consult a much fuller bibliography than the limits of this list will permit should turn to John Dillenberger's survey in Church History, June, 1956.

Sunderland.

A. SKEVINGTON WOOD.

\section{RELIGIOUS SYNCRETISM IN PTOLEMAIC TEXTS}

During the winter 1954/55, the writer took part in the archaeological excavations of the Mission Belge de Fouilles at El Kâb in Upper Egypt. After the dig he stayed one month at Karnak (Luqsor) to copy the unpublished texts covering the exterior walls of the Temple of Opet (Ptolemaic/Roman period). These walls are covered with inscriptions dating from the time of Caesar Augustus. They give geographical names, some of which were not known before.

During the winter 1955/56, he returned to Karnak where he spent another three months copying all the inscriptions covering the inside walls of the temple, which date for the greater part from the time of Ptolemy VIII Euergetes II (145-116 B.C.). These are religious texts which promise to be interesting for the study of syncretism in the Egyptian religion of later times. Some scenes show the Theban triad of Amun, Mut and Khonsu, but the epithets which accompany these gods are undoubtedly those of Orisis, Isis and Horus. The god Amun is represented in his own self, i.e. as one of the elements of the Ogdoad (the primeval forces before Creation), as father of the Eight (Ir-ta), as his own grandfather (Kematef) and as his own son (Amenopet). The point seems to be to try to explain how the son is not the inferior of the father, a problem which faced Christian theologians many centuries later. Such a tendency is already to be found in some Coffin Texts, which date from about 2000 B.C. The problems involved cannot be explained in a few words and we must refer to the writer's article 'A propos du temple d'Opet à Karnak', in the review Le Flambeau, a copy of which is to be found in Tyndale House Library. Any suggestion that the early Christian Fathers had knowledge of texts such as the Coffin Texts, which have been published only a few years ago by Professor A. de Buck of Leiden, must, of course, be rejected.

\section{NOTES AND NEWS}

C. de WIT.

\section{Recent Lectures at Tyndale House.}

Four Tyndale Lectures were delivered at Tyndale House in the course of the summer study groups: Mr. K. A. Kitchen on The Joseph Narratives and their Egyptian background '; Mr. E. A. Judge on 'Social Obligation in the New Testament '; Professor Gwyn Walters on 'The Intercession of the Spirit '; and Professor G. C. B. Davies on 'Some Aspects of the life of Henry Ryder, the first Evangelical Bishop'. Dr. Davies's lecture was the first of the new series of Tyndale Historical Theology Lectures. Mr. Judge having been appointed to a lectureship in the University of Sydney during the past year, his lecture was read in his absence.

In addition to these, there have been two lectures this year under the auspices of the Friends of Tyndale House. The late Professor Arndt spoke on the ArndtGingrich Lexicon on the day of its publication: and on a recent visit the Rev. 